\title{
ResearchOnline@JCU
}

This is the Accepted Version of a paper published in the journal Contemporary Nurse

Cheer, Karen, MacLaren, David, and Tsey, Komla (2015) The use of grounded theory in studies of nurses and midwives' coping processes: A systematic literature search. Contemporary Nurse, 51 (2-3). pp. 200-219.

http://dx.doi.org/10.1080/10376178.2016.1157445 


\section{The use of grounded theory in studies of nurses and midwives' coping processes: A systematic literature search}

\section{Karen Cheer, David MacLaren \& Komla Tsey}

To cite this article: Karen Cheer, David MacLaren \& Komla Tsey (2016): The use of grounded theory in studies of nurses and midwives' coping processes: A systematic literature search, Contemporary Nurse, DOI: 10.1080/10376178.2016.1157445

To link to this article: $h$ ttp://dx.doi.org/10.1080/10376178.2016.1157445

Accepted author version posted online: 24 Feb 2016.

Submit your article to this journal $[\pi$

Џll Article views: 7

Q View related articles $\llbracket$

View Crossmark data \lceil 
Publisher: Taylor \& Francis

Journal: Contemporary Nurse

DOI: $10.1080 / 10376178.2016 .1157445$

\section{The use of grounded theory in studies of nurses and midwives' coping processes: A systematic literature search}

Karen Cheer

College of Arts, Education and Society, James Cook University, PO Box 6811, Catrns, Australia

Corresponding author email: karen.cheer@my.jcu.edu.au

Telephone: +61742321257

David MacLaren

Division of Tropical Health and Medicine, James Cook University, PO Box 6811, Cairns, Australia

Email: david.maclaren@jcu.edu.au

Telephone: +61742321658

Komla Tsey

The Cairns Institute, James Cook University, PO Box 6811, Cairns, Australia

Email: komla.tsey@jcu.edu.au

Telephone: +61742321257 


\title{
The use of grounded theory in studies of nurses and midwives' coping processes: A systematic literature search
}

\author{
Karen Cheerl, David MacLaren ${ }^{2}$ and Komla Tsey ${ }^{3}$
}

Background: Researchers are increasingly using grounded theory methodologies to study the professional experience of nurses and midwives.

\begin{abstract}
Aim: To review common grounded theory characteristics and research design quality as described in grounded theory studies of coping strategies used by nurses and midwives
\end{abstract}

Methods: A systematic database search for 2005-2015 identified and assessed grounded theory characteristics from 16 studies. Study quality was assessed using a modified Critical Appraisal Skills Programme(CASP) tool.

Findings: Grounded theory was considered a methodology or a set of methods, able to be used within different nursing and midwifery contexts. Specific research requirements determined the common grounded theory characteristics used in different studies. Most researchers did not clarify their epistemological and theoretical perspectives.

Conclusion: To improve research design and trustworthiness of grounded theory studies in nursing and midwifery, researchers need to state their theoretical stance and clearly articulate their use of grounded theory methodology and characteristics in research reporting. 
Keywords: grounded theory, qualitative research, research design, nurses, midwives, coping strategies

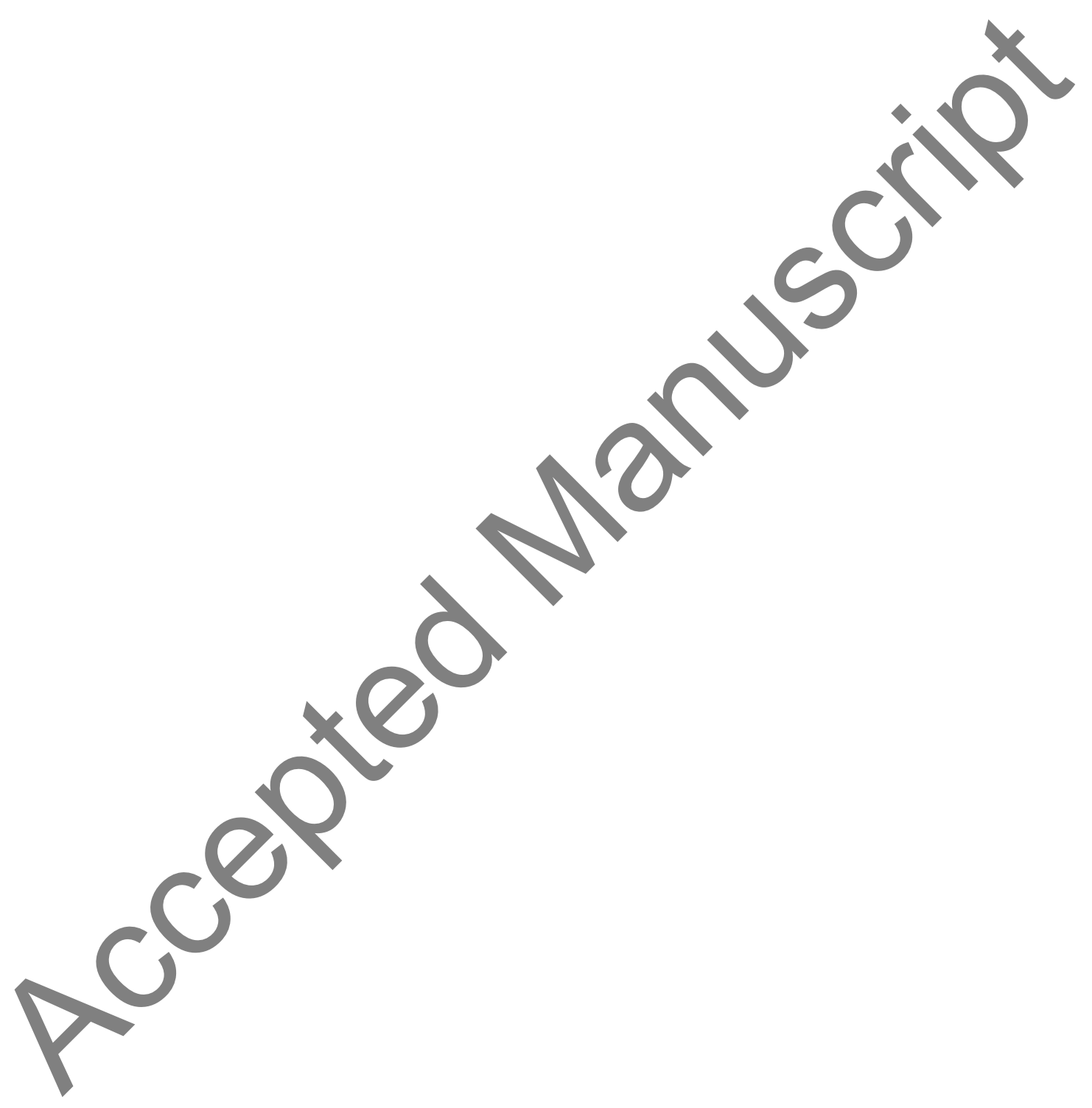




\section{Introduction}

Grounded theory methodology allows for socio-cultural contexts to be captured in the explanation of process and action related to a phenomenon or experience (Bryant \& Charmaz, 2010). Nurses and midwives' experiences in their working environments are many and varied and may be related to working conditions, the range of tasks undertaken and the relationships nurses and midwives have with colleagues, doctors, patients and their families (İlhan, 2008). A greater understanding of these complex issues has implications for nursing and midwifery education, practice and management. There are also methodological implications for researchers studying in this area.

Grounded theory is a popular methodology for qualitative research across disciplines (Bryant \& Charmaz, 2010). In their seminal 1967 text, Glaser and Strauss introduced a methodology designed to combine the strengths of both qualitative and quantitative approaches in response to the positivistic nature of social research at the time (Glaser \& Strauss, 1967; Suddaby, 2006; Walker \& Myrick, 2006). Grounded theory methods of analysis aim to assist researchers to better understand social phenomena, particularly in areas with little existing knowledge (Bainbridge, Whiteside, \& McCalman, 2013; Strauss, 1987). Grounded theory methodology is increasingly being used in nursing and midwifery research to study professional actions and interactions, facilitating the generation of theory concerning psychosocial processes (Elliott \& Lazenblatt, 2005; Wuest, 1995).

Disagreement over the nature of grounded theory resulted in a methodological estrangement between the creators (Greckhamer \& Koro-Ljungberg, 2005; Holton, 2008). Afterwards, Glaser extended the "classic" approach (Glaser, 1978, 1998, 2001). Strauss meanwhile, first explicated and then reformulated the approach, resulting in what is now known as the Straussian approach (Heath \& Cowley, 2004; Strauss, 1987). 
Over the past 40 years grounded theory has evolved and diversified to become a "family of methods" used by qualitative researchers in multiple ways (Bryant \& Charmaz, 2010, p. 11). Second-generation theorists have continued to build upon grounded theory's foundations, taking the original approach in new ontological and epistemological directions (Mills, Bonner, \& Francis, 2006). This includes constructivist grounded theory, the most widely known of the alternative versions and most recently, transformational grounded theory that integrates participatoryaction research and decolonizing methodologies (Charmaz, 2014; Redman-MacLaren \& Milts, 2015). Regardless of this evolution, there remains grounded theory family resemblances, or common characteristics apparent across the approaches. These include concurrent data analysis and collection, theoretical sampling, memo writing, theoretical sensitivity, coding processes, theoretical saturation, constant comparative methods and theorizing.

The diversification of approaches has led to criticism of blurred lines of methodologies, with researchers 'borrowing' components of grounded theory and the need for readers to critically assess papers published as grounded theory studies (Becker, 1993; Elliott \& Lazenblatt, 2005). Systematic reviews of the characteristics and study design quality of grounded research papers across disciplines and topic areas including nursing (Benoliel, 1996), exercise psychology (Hutchison, Johnston, \& Breckon, 2011; Weed, 2009), music therapy (O'Callaghan, 2012), speech and language therapy (Skeat \& Perry, 2008), accounting (Gurd, 2008), online and mobile customer behaviour (Valvi, Frangos, \& Frangos, 2013) and information systems (Matavire \& Brown, 2011), evidence the methodological discourse. To our knowledge a systematic review of grounded theory studies focusing on nurses and midwives' strategies of coping has not been published, despite the increased use of grounded theory in this area. This review aims to add to the 
body of nursing and midwifery research literature by identifying the characteristics and design quality of studies of nurses and midwives' coping strategies and improve our methodological understanding of the approach.

The research question was: How have the authors utilised grounded theory methods to study how nurses or midwives cope with work-related experiences? This comprised two parts:

a) How have grounded theory characteristics been applied in the studies?

b) What is the qualitative design quality of the studies?

\section{Methods}

A research protocol was developed and checked by two experienced qualitative researchers specialising in the grounded theory approach. The protocol outlined the methods of the search, selection criteria, analysis and assessment of the literature.

Search strategy

Figure 1 summarises the search strategy utilised for this review. The databases CINAHL, MEDLINE PsycINFO and PubMed were searched using a combination of the keywords nurse*, nursing, midwife*, midwive*, coping, cope* and grounded theory, together with database specific subject headings. Initial evaluation of the retrieved studies was undertaken by a review of the title and abstract. Citation searching of selected articles supplemented database searching.

\section{Applying inclusion/exclusion criteria}

Inclusion/exclusion criteria established at the outset of the search were applied to the retrieved studies. Publications were included where: 
- grounded theory approach was utilised

- $\quad$ study participants were nurses or midwives

- papers examined nurses or midwives' strategies of coping

- papers were published between January 2005 and March 2015 in peer reviewed journals

- papers were available in English

Studies focusing on health care workers other than nurses, midwives or nursing or

midwifery students/education were excluded. The search was not limited geographically. Accessibility of papers was reliant on availability via institutional subscriptions.

Figure 1. PRISMA Flowchart representing the selection process for included studies here

Data extraction

The data were extracted from the studies using a customized matrix. Study characteristics were categorized by: i) first author and year; ii) location; iii) setting; iv) participants; v) sample size; vi) participant gender; vii) study topic; viii) data collection methods; and ix) study type. Table 1 proyides a summary of the included studies and their characteristics. Methodological information informed by the common grounded theory characteristics was extracted from the studies and summarized in a matrix for analysis. The characteristics were: i) grounded theory approach cited; ii) data collection methods; iii) use of theoretical sampling; iv) theoretical sensitivity; v) use of memo writing; vi) constant comparison; vii) theoretical saturation; viii) coding and categorisation; and ix) theory generation. Studies were compared and contrasted to examine how grounded theory characteristics were utilised 
by the authors to generate substantive theory in the context of nursing or midwifery. Table 2 provides a summary of the application of grounded theory characteristics within the studies.

The quality of the selected studies was determined using a modified version of the Critical Appraisal Skills Program (CASP) Qualitative Research Checklist (2013). This generic tool enables systematic assessment of qualitative research. The CASP checklist was selected as it has been tested in various settings and offered prompts for answering each question to assist clarity for reviewers. Specific criteria assesses for clarity of research aims, the quality of the methodology, research design, recruitment strategies and relationships between the participants and the researcher, data collection and analysis, consideration of ethical issues, provision of a clear statement of the research findings and the value of the research. Modification of the checklist to indicate full, partial or nil inclusion of quality indicators allowed for ranking of the included papers. Criteria were rated as moderate (16-17 points), strong (18-19 points) or very strong (20 points). Table 3 provides a summary of the CASP quality assessment of the studies.

\section{Findings}

Study characteristics

Sixteen articles from 15 studies were identified for inclusion. The studies were published between 2005 and 2015, with nine (56\%) studies published after 2010. The studies typically aimed to explore nurses or midwives' views and experiences of work-related issues and the coping processes they utilised to overcome challenges. Researchers affiliated with academic institutions or clinical settings conducted the studies. Twelve $(75 \%)$ of the studies were from western, industrialised countries while four (25\%) of the studies were from Asian countries (Table 1, Column 1). Seven (44\%) of the studies were undertaken in urban areas; two (12\%) of the studies were undertaken in regional areas; one $(6 \%)$ of the studies was undertaken in a 
rural area; one $(6 \%)$ of the studies was undertaken across metropolitan, rural and regional areas; and five (31\%) of the studies did not specify the setting (Table 1, Column 2). Sample sizes ranged from 10-104 $(\mathrm{Mdn}=22)$. Ten $(62 \%)$ studies reported a sample size of less than 20 participants. Only one (6\%) study had a sample size over 100 (Table 1, Column 4). One $(6 \%)$ of the studies recruited only male participants; four $(25 \%)$ of the studies recruited only female participants; seven (44\%) of the studies recruited both male and female participants, while four (25\%) of the studies did not state participant gender (Table 1, Column 5). Fourteen $(88 \%)$ of the studies employed qualitative data collection methods, while two $(12 \%)$ of the studies utilised both qualitative and quantitative methods (Table 1, Column 7).

Table 1. Summary of included studies and characteristics here.

\section{Approaches and modifications}

Studies used three terms when referring to grounded theory. Three (19\%) of the studies referred to it as a methodology; seven (44\%) of the studies referred to it as a method; four $(25 \%)$ of the studies referred it as both methodology and method; and two (12\%) of the studies used neither term. Onty two $(12 \%)$ of the studies did not indicate a rationale for using grounded theory (Table 2, Column 1). Three (19\%) of the studies referenced the 1967 Glaser and Strauss text; five (31\%) of the studies referenced a Glaser text $(1978,1992,1998)$; eight $(50 \%)$ of the studies referenced a Strauss and Corbin text $(1990,1998,2007)$; and two $(12 \%)$ of the studies referenced the constructivist text of Charmaz (2006). Two (12\%) of the studies cited the texts of Strauss and Corbin (1998) and Charmaz (2006). One (6\%) of the studies cited the modified grounded theory approach (M-GTA) developed by Japanese sociologist Yasuhito Kinoshita. One (6\%) of the studies cited Glaser and Strauss (1967), applying Pargament's coping theory for interpretive purposes. One (6\%) of the studies cited Strauss 
and Corbin (1990) methods for data categorisation, applying the stress model of Carson and Kuipers as a framework for investigation (Table 2, Column 1).

\section{Data collection}

All studies described data collection methods. Nine (56\%) of the studies utilised semistructured or open-ended participant interviews. Three (19\%) of the studies utilised interviews and participant observation. Two (12\%) of the studies utilised interviews and focus groups. One $(6 \%)$ of the studies utilised focus groups only. One $(6 \%)$ of the studies utilised multiple data collection sources including demographic data, interviews, memos and journaling, diagrams and conceptual models, literature and documents (Table 2, Column 2). Memo writing was reported in ten (63\%) of the selected studies (Table 2, Column 5). Two $(12 \%)$ of the studies utilised memos, field notes and literature as data sources. Two $(12 \%)$ of the studies supplemented data from interviews with data gathered from quantitative measurement scales. Both these studies noted these measurements were used for descriptive purposes, while one $(6 \%)$ of the studies stated use of quantitative analysis also allowed for objective measurement of the degree to which participants coped (Table 2, Column 2). Concurrent data collection and analysis was specifically noted in nine (56\%) of the studies or implied in three (19\%) studies (Table 2, Column 3).

\section{Sampling, saturation and constant comparison}

Twelve $(75 \%)$ of the studies indicated theoretical sampling, the iterative process of concurrent data collection and analysis achieving theoretical saturation. Of the remaining, two $(12 \%)$ of the studies indicated the use of snowball sampling to recruit participants, while three (19\%) of the studies (Table 2, Column 3) indicated the use of purposive sampling. Constant comparison was explicitly noted in twelve (75\%) of the studies and implicit in a further three (19\%) of the studies, with comparison occurring during concurrent data 
collection and analysis, the coding process or throughout the research process. One $(6 \%)$ of the studies provided insufficient detail to indicate use of the technique (Table 2, Column 6).

Table 2. Summary of application of grounded theory characteristics here.

\section{Coding}

Fourteen (88\%) of the studies employed coding levels including open, axial and/or selective coding. Of these studies, nine (56\%) reported identification of a core category, variable or central phenomenon. One (6\%) of the studies using M-GTA conceptualised variations related to the focused theme and person. These derivations were further refined and categorised. One $(6 \%)$ of the studies analysed data using Kvale's model of analysis, where "the first stage is carried out inductively, with categories and themes being sought. The second stage is an abductive process, moving between empirical and theoretical perspectives." Only three studies indicated the use of qualitative analytical software (Table 2, Column 8).

\section{Theoretical Sensitivity}

All studies used existing literature to situate their research within the larger context of the phenomenon under investigation. Six $(38 \%)$ of studies indicated the characteristic of theoretical sensitivity. One $(6 \%)$ of the studies specified theoretical sensitivity during the research process. Four (25\%) of the studies specified reflexivity during the research process. One $(6 \%)$ of the studies used the literature to develop sensitising concepts at the outset of the research. Only one $(6 \%)$ of the studies employed the M-GTA that recognises the importance of researcher positioning in the epistemology of the project, however this was not explicit in the report. Two (12\%) of the studies undertook a literature review after formation of a substantive theory. One (6\%) of the studies specified bracketing (the setting aside) of experiential and personal knowledge to reduce bias (Table 2, Column 4). 


\section{Presentation of research findings}

Eight $(50 \%)$ of the studies claimed theory generation. Two (12\%) of the studies presented findings as a conceptual model. One $(6 \%)$ of the studies situated findings within the stress model devised by Carson and Kuipers to gain an understanding of the phenomenon under focus. One $(6 \%)$ of the studies utilised storylines to help construct and present the description of categories. Four (25\%) of the studies presented findings as dimensions of a core theme(s) (Table 2, Column 9).

Quality assessment

The studies were assessed for quality using a modified version of the CASP checklist. All studies were published in peer-reviewed journals. Three (19\%) of the studies met all criteria and rated very strong; three (19\%) of the studies rated strong; and ten (63\%) of the studies rated moderate. Studies were rated moderate to strong where limited or absent description of researcher positioning, or data collection/analysis did not fully meet the modified criteria (Table 3).

Table 3. Summary of CASP quality assessment of studies here.

\section{Discussion}

Articles on nurses or midwives' coping processes in this review utilized varied grounded theory approaches and characteristics from the classic to contemporary versions. Research findings were presented as substantive theories, placed within conceptual models or as thematic descriptions. Grounded theory was described as a methodology, a method, or as both a methodology and a method. The literature documents a common confusion of a definition amongst grounded theorists, with even the co-founders sending mixed messages (Elharidy, Nicholson, \& Scapens, 2008; Tan, 2010). Glaser and Houlton (2004, p.10) defined 
grounded theory as "a conceptual theory generating methodology" using constant comparative methods, while Strauss and his co-author Corbin, described grounded theory as both a qualitative methodology and a research method utilizing systematic procedures (Corbin \& Strauss, 2015; Strauss \& Corbin, 1990). Feminist, religious or cultural methodologies informed some of the reviewed studies. Researchers conducting studies informed by other methodologies often use grounded theory methods because they are analytically valuable (Birks \& Mills, 2015).

Although identifying as grounded theory research few of the reviewed studies discussed use of the suite of grounded theory characteristics, despite the systematic processes of grounded theory making it unique amongst research methods (Elharidy et al., 2008; Skeat \& Perry, 2008). Nursing and midwifery researchers in this review primarily used grounded theory data analysis techniques in only the analysis phase of their studies. The majority of the reviewed studies utilized analytical methods informed by the Strauss and Corbin approach. The popularity of this method for data collection and analysis may be due to its clear, highly structured nature (Babchuk, 2011, Matavire \& Brown, 2011; McCann \& Clark, 2003b). Selective use of grounded theory characteristics has been criticised (Becker, 1993; Cutcliffe, 2005) with Glaser (2010,p.1) proclaiming "[research] is grounded theory only when it follows the [classic] grounded theory methodological package". Conversely, the positivist foundations of classic grounded theory have been challenged by contemporary social constructionist and post-positivist reconstructions (Charmaz, 2008). While it has been advised that researchers select and consistently apply one approach, others maintain grounded theory is flexible, and versions may be adopted or combined as required (Babchuk, 2011; Charmaz, 2014; Tan, 2010).

Most authors did not discuss the use of qualitative analytical software (QAS) even though QAS is increasingly being utilized by researchers (Ahmad \& Newman, 2010; O'Reilly, 
2009). Studies reporting usage of QAS applied QSR's NVivo software, one of the most popular software programs (SAGE, 2014). QAS is a useful tool for data storage and management, manual coding, auditing, and enables transparency of the research process yet limitations include the time and skills needed by the researcher to learn a program and the inability of QAS to analyse data and develop theory (Cope, 2014; O'Reilly, 2009). Findings from this review support the view that researchers use QAS for coding, and adopt manual methods for conceptual analysis and theory development (Ahmad \& Newman, 2010). The results indicated there is potential for greater use of QAS by grounded theory researchers, if only for storage and coding of data.

Of particular note was that the majority of authors in the reviewed studies demonstrated a lack of detail in epistemological and theoretical positioning. Grounded theory researchers should justify their choice or combination of a particular yersion(s) and fully articulate how each characteristic was utilized (Babchuk, 2011; Tan, 2010). Furthermore, researchers need an awareness of the nature of their selected approach and to acknowledge their own assumptions, because the theoretical perspective of the researcher, which is in turn informed by an epistemology, informs the selection of a grounded theory methodology and methods use (Birks \& Mills, 2015; Crotty, 1998; Elharidy et al., 2008). Clear justification of the methodology and methods, together with explication of the underlying theoretical perspective and epistemology ensures a strong research design and valid and convincing outcomes of research(Crotty, 1998; Mills, Bonner, \& Francis, 2008).

The majority of studies did not meet the CASP criteria of adequate consideration of the researcher/participant relationship. Examination of their role in the research process and how they respond to events throughout the study are elements for the researcher to consider and address (Critical Appraisal Skills Programme (CASP), 2013). Researchers and participants bring individual worldviews, experience and knowledge to the research project (Charmaz, 
2014). A reciprocal relationship where views and beliefs are shared between researcher and participant is crucial, because it is via this interaction that an understanding of meaning and behaviours, and therefore knowledge, is constructed (Mallory, 2001). In studies designed to emphasize social, cultural or other differences, researchers must be cognisant that divergent characteristics of the participants and themselves may impact on interaction, thereby affecting the data collection and analysis process (Mallory, 2001). Acknowledging relationship differences enables the researcher to: i) position themselves in the research process and findings; ii) gain insight into the basic social and psychosocial processes experienced by participants and iii) explicate differences to increase credibility of research findings (Charmaz, 2014; Mallory, 2001).

Qualitative data gathering methods were preferred by authors of the reviewed papers, with the use of quantitative data collection methods reported in only two of the studies. Despite the "all is data" approach, (Glaser, 1998, p. 8) few of the reviewed studies combined qualitative and quantitative data. Surprisingly, most studies utilized only one or two methods for data collection. Interviews were the most popular data collection method. This finding is supported by the extant literature, which shows that although a range of qualitative and quantitative data collection methods can be used in grounded theory studies, most researchers selected interviews as the principle method for data collection (Birks \& Mills, 2015; Glaser \& Houlton, 2004). Nurse researchers using only interview data may produce studies that focus on participants' lived experiences rather than the social processes or changes over time (McCann, 2003a). All types of data can be collected and analysed in grounded theory, thereby expanding the constant comparison method (Glaser, 1998). More case studies are needed to demonstrate how qualitative and quantitative data can be combined in grounded theory research. Using a range of data gathering methods can strongly substantiate findings, thereby adding value to the grounded theory (Birks \& Mills, 2015). 
Sample sizes for interviews were varied throughout the studies. The question of how many interviews should be conducted in qualitative research is contested (Baker \& Edwards, 2012; Mason, 2010). Sample size in grounded theory studies is usually guided by the principle of theoretical saturation (Creswell, 2013). However, there is debate among researchers about what characterises saturation and how it may be recognized (Charmaz, 2014). The research question and objectives, analytical development during theoretical sampling, and the quality of data are all important factors in determination of sample size (Charmaz, 2014) Consideration of these factors can guide researchers so that sample size is sufficient to achieve "excellence, rather than adequacy" in level of analysis and subsequent theory construction (Charmaz, 2014, p. 108).

Studies varied in the reporting of research design and the utilization of grounded theory characteristics as outlined in the CASP inclusion criteria for qualitative studies. It is unclear in this review whether authors failed to report explicit details of theoretical perspectives, methodology or research procedures because of limitations in journal manuscript submission criteria or because they did not adhere to grounded theory processes (Hutchison et al., 2011). This was particularly apparent in the study by Lipp and Fothergill (2009), which provided a synopsis of the earlier study by Lipp (2008), and referred readers to that study for details of research design and process. As there is no formula for reporting grounded theory studies, it may be difficult for both authors and editors to include all relevant information in published research that enables true quality assessment (Hutchison et al., 2011).

\section{Conclusion}

Grounded theory is a contested and evolving research methodology. The findings from this review provide evidence that researchers of nurses and midwives' coping processes utilized a range of grounded theory approaches. Few studies indicated the use of all common grounded 
theory characteristics. Authors selectively used grounded theory characteristics according to the requirements of their research or their use of other methodological frameworks. Researchers predominantly used qualitative data collection techniques and structured methods in the data analysis phase. A minority of researchers chose to use qualitative analysis software. Most researchers did not clarify the epistemological and theoretical perspectives underpinning their use of grounded theory methodology, nor did they explicate the relationship between themselves as researcher and the study participants This has implications not only for research design but also for trustworthiness of the research. To improve grounded theory research in nursing and midwifery, researchers need to identify their theoretical stance and clearly articulate their use of grounded theory methodology and characteristics in research reporting.

\section{Authors' contributions}

$\mathrm{KC}, \mathrm{KT}$ and DM conceived of the study and participated in the study design. $\mathrm{KC}$ took the lead role in database searching, reviewing the literature, data extraction and analysis, quality assessment of publications and drafted the paper. All authors edited and revised the draft paper and approved the final manuscript.

\section{Author details}

${ }^{1}$ The College of Arts, Society and Education, James Cook University, McGregor Rd, Smithfield 4878, Australia. ${ }^{2}$ Division of Tropical Health and Medicine, James Cook University, McGregor Rd, Smithfield 4878, Australia. ${ }^{3}$ The Cairns Institute, James Cook University, McGregor Rd, Smithfield 4878, Australia. 


\section{References}

Ahmad, A., \& Newman, M. (2010). Computer-assisted qualitative data analysis software: An illustration of limitations and advantages. AMCIS 2010 Proceedings, Paper 134. Retrieved from: http://aisel.aisnet.org/amcis2010/134

Asakura, K., \& Watanabe, I. (2011). Survival strategies of male nurses in rural areas of Japan. Japan Journal of Nursing Science, 8(2), 194-202. doi: 10.1111/j.1742-7924.2011.00176.x

Babchuk, W. A. (2011). Grounded theory as a "family of methods": A genealogical analysis to guide research. US-China Education Review, 8(9), 383-388.

Bainbridge, R., Whiteside, M., \& McCalman, J. (2013). Being, knowing, and doing: a phronetic approach to constructing grounded theory with Aboriginal Australian partners. Qual Health Res, 23(2), 275-288. doi: 10.1177/1049732312467853

Baker, S. E., \& Edwards, R. (2012). How many qualitative interviews is enough?: Expert voíces and early career reflections on sampling and cases in qualitative research. National centre for Research Methods Review Paper. Retrieved 3 August 2015, from http://eprints.brighton.ac.uk/11632/

Becker, P. H. (1993). Common pitfalls in published grounded theory research. Qualitative Health Research, 3(2), 254-260. doi: 10.1177/104973239300300207

Benoliel, J. Q. (1996). Grounded theory and nursing knowledge. Qualitative Health Research, 6(3), 406-428.

Birks, M., \& Mills, J. (2015). Grounded theory: A practical guide (2nd ed.). London: SAGE.

Boroujeni, A. Z., Mohammadi, R., Oskouie, S. F., \& Sandberg, J. (2009). Iranian nurses' preparation for loss: finding a balance in end-of-life care. J Clin Nurs, 18(16), 2329-2336. doi: 10.1111/j.1365-2702.2008.02437.x

Bryant, A., \& Charmaz, K. (2010). The SAGE handbook of grounded theory. Los Angeles: SAGE Publications.

Charmaz, K. (2008). Reconstructing grounded theory. In P. Alasuutari, L. Bickman, \& J. Brannen (Eds.), The SAGE handbook of social research methods (pp. 461-479). Los Angeles: SAGE.

Charmaz, K. (2014). Constructing grounded theory (2nd ed.). Thousand Oaks, California: SAGE Publications.

Cope, D. G. (2014). Computer-assisted qualitative data analysis software. Oncol Nurs Forum, 41(3), 322-323. doi: 10.1188/14.ONF.322-323

Corbin, J., \& Strauss, A. L. (2015). Basics of qualitative research: Techniques and procedures for developing grounded theory (4th ed.). Thousand Oaks, CA: SAGE Publications.

Creswell, J. W. (2013). Qualitative inquiry and research design: Choosing among five approaches (3rd ed.). Thousand Oaks, California: SAGE Publications.

Critical Appraisal Skills Programme (CASP). (2013). CASP Qualitative Research Checklist. from http://media.wix.com/ugd/dded87 29c5b002d99342f788c6ac670e49f274.pdf

Crotty, M. (1998). The foundation of social research: Meaning and perspective in the research process. St Leonards, N.S.W.: Allen \& Unwin.

Cutcliffe, J. R. (2005). Adapt or adopt: Developing and transgressing the methodological boundaries of grounded theory. Journal of Advanced Nursing, 51(4), 421-428.

Dolan, G., Strodl, E., \& Hamernik, E. (2012). Why renal nurses cope so well with their workplace stressors Journal of Renal Care, 38(4), 222-232. doi: 10.1111/j.1755-6686.2012.00319.x

Ekedahl, M., \& Wengström, Y. (2006). Nurses in cancer care: Coping strategies when encountering existential issues. European Journal of Oncology Nursing, 10(2), 128-139.

Elharidy, A. M., Nicholson, B., \& Scapens, R. W. (2008). Using grounded theory in interpretitive management accounting research. Qualitative Research in Accounting \& Management, 5(2), 139-155. doi: 10.1108/11766090810888935

Elliott, N., \& Lazenblatt, A. (2005). How to recognise a 'quality' grounded theory research study. Australian Journal of Advanced Nursing, 22(3), 48-52.

Furber, C. M., \& Thomson, A. M. (2007). Midwives in the UK: An exploratory study of providing newborn feeding support for postpartum mothers in the hospital. J Midwifery Womens Health, 52(2), 142-147. doi: 10.1016/j.jmwh.2006.10.016 
Glaser, B. G. (1978). Theoretical sensitivity: Advances in the methodology of grounded theory. Mill Valley, Calif: Sociology Press.

Glaser, B. G. (1998). Doing grounded theory: Issues and discussions. Mill Valley, Calif: Sociology Press.

Glaser, B. G. (2001). The grounded theory perspective: Conceptualization contrasted with description. Mill Valley, CA: Sociology Press.

Glaser, B. G. (2010). The future of grounded theory. Grounded Theory Review, 9(2), 1-14.

Glaser, B. G., \& Houlton, J. A. (2004). Remodelling grounded theory. Grounded Theory Review, 4(1), $1-24$.

Glaser, B. G., \& Strauss, A. L. (1967). The discovery of grounded theory: Strategies for qualitative research. Chicago: Aldine.

Greckhamer, T., \& Koro-Ljungberg, M. (2005). The erosion of a method: Examples from grounded theory. International Journal of Qualitative Studies in Education, 18(6), 729-750. doi. $10.1080 / 09518390500298204$

Gurd, B. (2008). Remaining consistent with method? An analysis of grounded theory research in accounting. Qualitative Research in Accounting \& Management, 5(2), 92-100. doi: 10.1108/11766090810888908

Heath, H., \& Cowley, S. (2004). Developing a grounded theory approach: A comparison of Glaser and Strauss. International Journal of Nursing Studies, 41(2), 141-150. doi:10.1016/s00207489(03)00113-5

Holton, J. A. (2008). Grounded theory as a general research methodology Grounded Theory Review, 7(2). Retrieved from: http:/groundedtheoryreview.com/2008/06/30/grounded-theory-as-ageneral-research-methodology/

Hutchison, A. J., Johnston, L., \& Breckon, J. (2011). Grounded theory-based research within exercise psychology: A critical review. Qualitative Research in Psychology, 8(3), 247-272. doi: 10.1080/14780880903304527

İlhan, M. N., Durukan, E., Taner, E., Maral, I., \& Bumin, M. A. (2008). Burnout and its correlates among nursing staff: Questionnaire survey. Journal of Advanced Nursing, 61(1), 100-106. doi: $10.1111 / \mathrm{j} .1365-2648.2007 .04476 . x$

Jamieson, L. N., Williams, L. M., Lauder, W., \& Dwyer, T. (2008). The 'realities' of part-time nursing: A grounded theory study. Journal of Nursing Management, 16(7), 883-892. doi: $10.1111 / \mathrm{j} .1365-2934.2007 .00836$.

Jannati, Y., Mohammadi, R., \& Seyedfatemi, N. (2011). Iranian clinical nurses' coping strategies for job stress. J Occup Health, 53, 123-129.

Lagerstrom, M., Josephson, M., Arsalani, N., \& Fallahi-Khoshknab, M. (2010). Striving for balance between family and work demands among Iranian nurses. Nurs Sci Q, 23(2), 166-172. doi: $10.1177 / 0894318410362543$

Lipp, A. (2008). A woman centred service in termination of pregnancy: A grounded theory study. Contemporary Nurse: A Journal for the Australian Nursing Profession, 31(1), 9-19. doi: $10.5172 /$ conu. 673.31 .1 .9

Lipp, A., \& Fothergill, A. (2009). Nurses in abortion care: Identifying and managing stress.

Contemporary Nurse: A Journal for the Australian Nursing Profession, 31(2), 108-120. doi: 10.5172/conu.673.31.2.108

Mallory, C. (2001). Examining the differences between researcher and participant: An intrinsic element of grounded theory. In R. S. Schreiber \& P. N. Stern (Eds.), Using grounded theory in nursing (pp. 85-95). New York, NY, USA: Springer Publishing Company.

Mason, M. (2010). Sample size and saturation in PhD studies using qualitative interviews. Forum Qualitative Sozialforschung / Forum: Qualitative Social Research, 11(3). Retrieved from: http://www.qualitative-research.net/index.php/fqs/article/view/1428/3027

Matavire, R., \& Brown, I. (2011). Profiling grounded theory approaches in information systems research. European Journal of Information Systems, 22(1), 119-129. doi: 10.1057/ejis.2011.35

McCann, T. V., \& Clark, E. (2003a). Grounded theory in nursing research: Part 2 - Critique. Nurse Researcher, 11(2), 19-28. 
McCann, T. V., \& Clark, E. (2003b). Grounded theory in nursing research: Part 3 - Application. Nurse Researcher, 11(2), 29-39.

Mills, J., Bonner, A., \& Francis, K. (2006). Adopting a constructivist approach to grounded theory: Implications for research design. Internation Journal of Nursing Practice, 12(1), 8-13. doi: 10.1111/j.1440-172X.2006.00543.x

Mills, J., Bonner, A., \& Francis, K. (2008). The development of constructivist grounded theory. International Journal Of Qualitative Methods, 5(1), 25-35.

Musto, L., \& Schreiber, R. S. (2012). Doing the best I can do: moral distress in adolescent mental health nursing. Issues Ment Health Nurs, 33(3), 137-144. doi: $10.3109 / 01612840.2011 .641069$

O'Callaghan, C. (2012). Grounded therapy in music therapy research. Journal of Music Therapy, 49(3), 236-277.

O'Reilly, K. (2009). Computer Software (Caqdas) Key concepts in ethnography (pp. 39-44). London: SAGE Publications.

Peterson, J., Johnson, M., Halvorsen, B., Apmann, L., Chang, P.-C., Kershek, S., . . Pincon, D. (2010). Where do nurses go for help? A qualitative study of coping with death and dying. International journal of palliative nursing, 16(9), 432, 434.

Redman-MacLaren, M. L., \& Mills, J. (2015). Transformational grounded theory: Theory, voice and action. International Journal Of Qualitative Methods, 14(3), 1-12

SAGE. (2014). Qualitative Data Analysis Software Resource Centre. Retrieved 19 May, 2015, from http://www.sagepub.com/qdas/

Sandgren, A., Thulesius, H., Fridlund, B., \& Petersson, K. (2006). Striving for emotional survival in palliative cancer nursing. Qual Health Res, 16(1), 79-96. doi: 10.1177/1049732305283930

Skeat, J., \& Perry, A. (2008). Grounded theory as a method for research in speech and language therapy. International Journal of Language \& Communication Disorders, 43(2), 95-109. doi: 10.1080/13682820701437245

Slatyer, S., Williams, A. M., \& Michael, R. (2015). Seeking empowerment to comfort patients in severe pain: A grounded theory study of the nurse's perspective. International Journal of Nursing Studies, 52(1), 229-239. doi: 10.1016/j.ijnurstu.2014.06.010

Smith, Z., Leslie, G., \& Wynaden, D. (2015). Australian perioperative nurses' experiences of assisting in multi-organ procurement surgery: A grounded theory study. International Journal of Nursing Studies, 52(3), 705-715. doi:10.1016/j.ijnurstu.2014.12.004

Strauss, A. L. (1987). Qualitative analysis for social scientists. Cambridge [Cambridgeshire]; New York: Cambridge University Press.

Strauss, A. L., \& Corbin, J., M. (1990). Basics of qualitative research: Grounded theory procedures and techniques. Newbury Park, CA: SAGE Publications.

Suddaby, R. (2006). From the editors: What grounded theory is not. Academy of Management Journal, 49(4), 633-642.

Tan, J. (2010). Grounded theory in practice: Issues and discussion for new qualitative researchers. Journat of Documentation, 66(1), 93-112. doi: 10.1108/00220411011016380

Valvi, A. C., Frangos, C. C., \& Frangos, C. C. (2013). Online and mobile customer behaviour: A critical evaluation of grounded theory studies. Behaviour \& Information Technology, 32(7), 655-667. doi: 10.1080/0144929X.2013.789082

Walker, D., \& Myrick, F. (2006). Grounded theory: An exploration of process and procedure. Qualitative Health Research, 16(4), 547-559. doi: 10.1177/1049732305285972

Weed, M. (2009). Research quality considerations for grounded theory research in sport \& exercise psychology. Psychology of Sport and Exercise, 10(5), 502-510. doi: 10.1016/j.psychsport.2009.02.007

Wilson, D., \& Baker, M. (2012). Bridging two worlds: Maori mental health nursing. Qualitative Health Research, 22(8), 1073-1082. doi: 10.1177/1049732312450213

Wuest, J. (1995). Feminist grounded theory: An exploration of the congruency and tensions between two traditions in knowledge discovery. Qualitative Health Research, 5(1), 125-137. doi: $10.1177 / 104973239500500109$ 


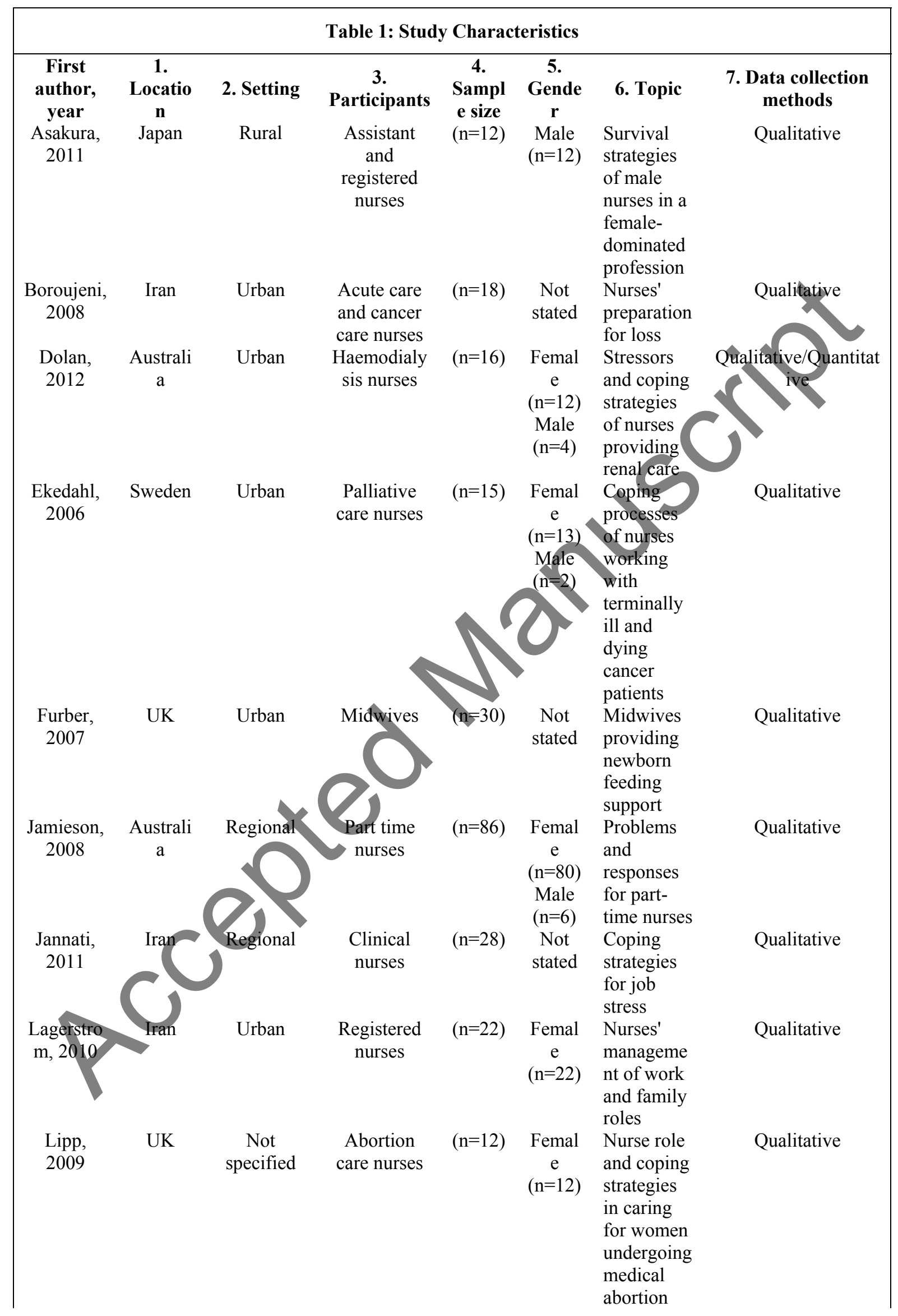




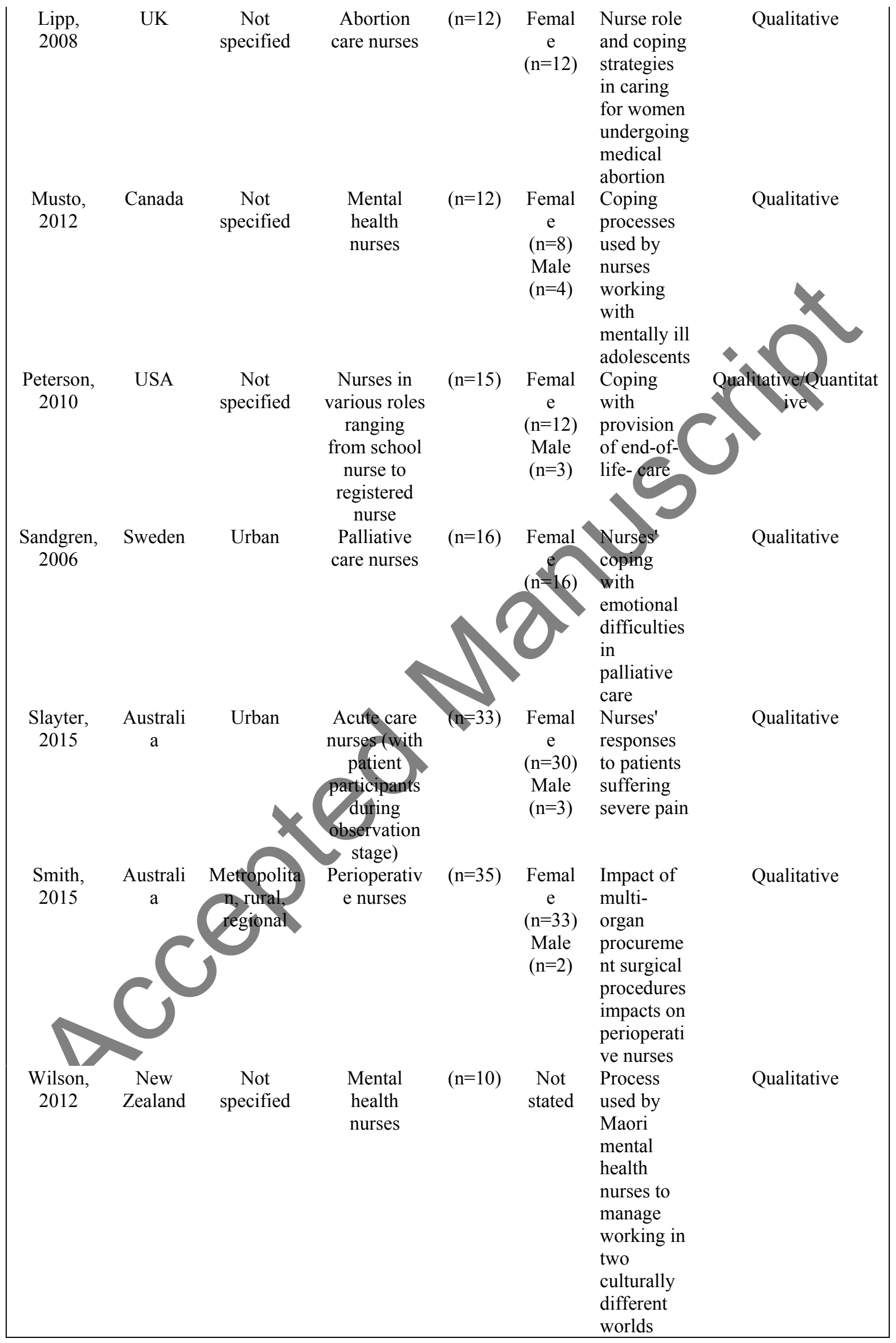


Table 2. Application of Grounded Theory Characteristics

\begin{tabular}{|c|c|c|c|c|c|c|c|c|c|}
\hline $\begin{array}{c}\text { First } \\
\text { autho } \\
\text { r, } \\
\text { year }\end{array}$ & $\begin{array}{c}1 . \\
\text { Groun } \\
\text { ded } \\
\text { theory } \\
\text { appro } \\
\text { ach }\end{array}$ & $\begin{array}{c}\text { 2. Data } \\
\text { collectio } \\
\mathbf{n} \\
\text { method } \\
\quad \mathrm{s}\end{array}$ & $\begin{array}{c}3 . \\
\text { Theore } \\
\text { tical } \\
\text { sampli } \\
\text { ng }\end{array}$ & $\begin{array}{c}4 . \\
\text { Theor } \\
\text { etical } \\
\text { sensiti } \\
\text { vity }\end{array}$ & $\begin{array}{c}5 . \\
\text { Me } \\
\text { mo } \\
\text { writ } \\
\text { ing }\end{array}$ & $\begin{array}{c}6 . \\
\text { Const } \\
\text { ant } \\
\text { comp } \\
\text { arison }\end{array}$ & $\begin{array}{l}7 . \\
\text { Theor } \\
\text { etical } \\
\text { Satur } \\
\text { ation }\end{array}$ & $\begin{array}{c}8 . \\
\text { Coding } \\
\text { and } \\
\text { categor } \\
\text { isation }\end{array}$ & $\begin{array}{c}9 . \\
\text { Theory } \\
\text { generati } \\
\text { on }\end{array}$ \\
\hline $\begin{array}{l}\text { Asaku } \\
\text { ra, } \\
2011\end{array}$ & $\begin{array}{l}\text { M- } \\
\text { GTA: } \\
\text { an } \\
\text { altered } \\
\text { version } \\
\text { Glaser } \\
\text { and } \\
\text { Strauss } \\
\text { (1967). } \\
\text { GT as } \\
\text { a } \\
\text { metho } \\
\text { d. }\end{array}$ & $\begin{array}{l}\text { Semi- } \\
\text { structure } \\
\text { d } \\
\text { intervie } \\
\text { ws } \\
(p .195) .\end{array}$ & $\begin{array}{l}\text { No. } \\
\text { Purposi } \\
\text { ve } \\
\text { sampli } \\
\text { ng } \\
\text { (p.195) }\end{array}$ & No. & No. & No. & No & $\begin{array}{l}\text { Concep } \\
\text { ts } \\
\text { derived } \\
\text { from } \\
\text { interpre } \\
\text { tation } \\
\text { of } \\
\text { variatio } \\
\text { ns } \\
\text { related } \\
\text { to } \\
\text { theme } \\
\text { and } \\
\text { person, } \\
\text { and } \\
\text { other } \\
\text { variatio } \\
\text { ns from } \\
\text { data. } \\
\text { Concep } \\
\text { ts } \\
\text { refined } \\
\text { accordi } \\
\text { ng to } \\
\text { variatio } \\
\text { ns. } \\
\text { Categor } \\
\text { ies } \\
\text { deduce } \\
\text { d from } \\
\text { concept } \\
\mathrm{s}, \\
\text { relation } \\
\text { ships } \\
\text { betwee } \\
\mathrm{n} \\
\text { categori } \\
\text { es } \\
\text { examin } \\
\text { ed and } \\
\text { mapped } \\
\text { (p.195). }\end{array}$ & $\begin{array}{l}\text { Use of } \\
\text { storyline } \\
\text { s (p. } \\
\text { 196). } \\
\text { Describe } \\
\text { s four } \\
\text { aspects } \\
\text { to the } \\
\text { survival } \\
\text { strategy } \\
\text { of rural } \\
\text { male } \\
\text { nurses in } \\
\text { Japan } \\
\text { (p.202). }\end{array}$ \\
\hline $\begin{array}{l}\text { Borou } \\
\text { jeni, } \\
2008\end{array}$ & $\begin{array}{l}\text { Strauss } \\
\text { and } \\
\text { Corbin } \\
\text { (1998). } \\
\text { GT as } \\
\text { a }\end{array}$ & $\begin{array}{l}\text { Semi- } \\
\text { structure } \\
\text { d } \\
\text { intervie } \\
\text { ws } \\
\text { (p.2331) }\end{array}$ & $\begin{array}{l}\text { Yes } \\
\text { (p.2330 } \\
\text { ). } \\
\text { Concur } \\
\text { rent } \\
\text { data } \\
\text { collecti }\end{array}$ & No. & No. & $\begin{array}{l}\text { Yes } \\
\text { (p.233 } \\
1) .\end{array}$ & No. & $\begin{array}{l}\text { Open, } \\
\text { axial } \\
\text { and } \\
\text { selectiv } \\
\text { e } \\
\text { coding } \\
\text { to }\end{array}$ & $\begin{array}{l}\text { Four } \\
\text { dimensio } \\
\text { ns of } \\
\text { core } \\
\text { theme of } \\
\text { "Finding } \\
\text { a }\end{array}$ \\
\hline
\end{tabular}




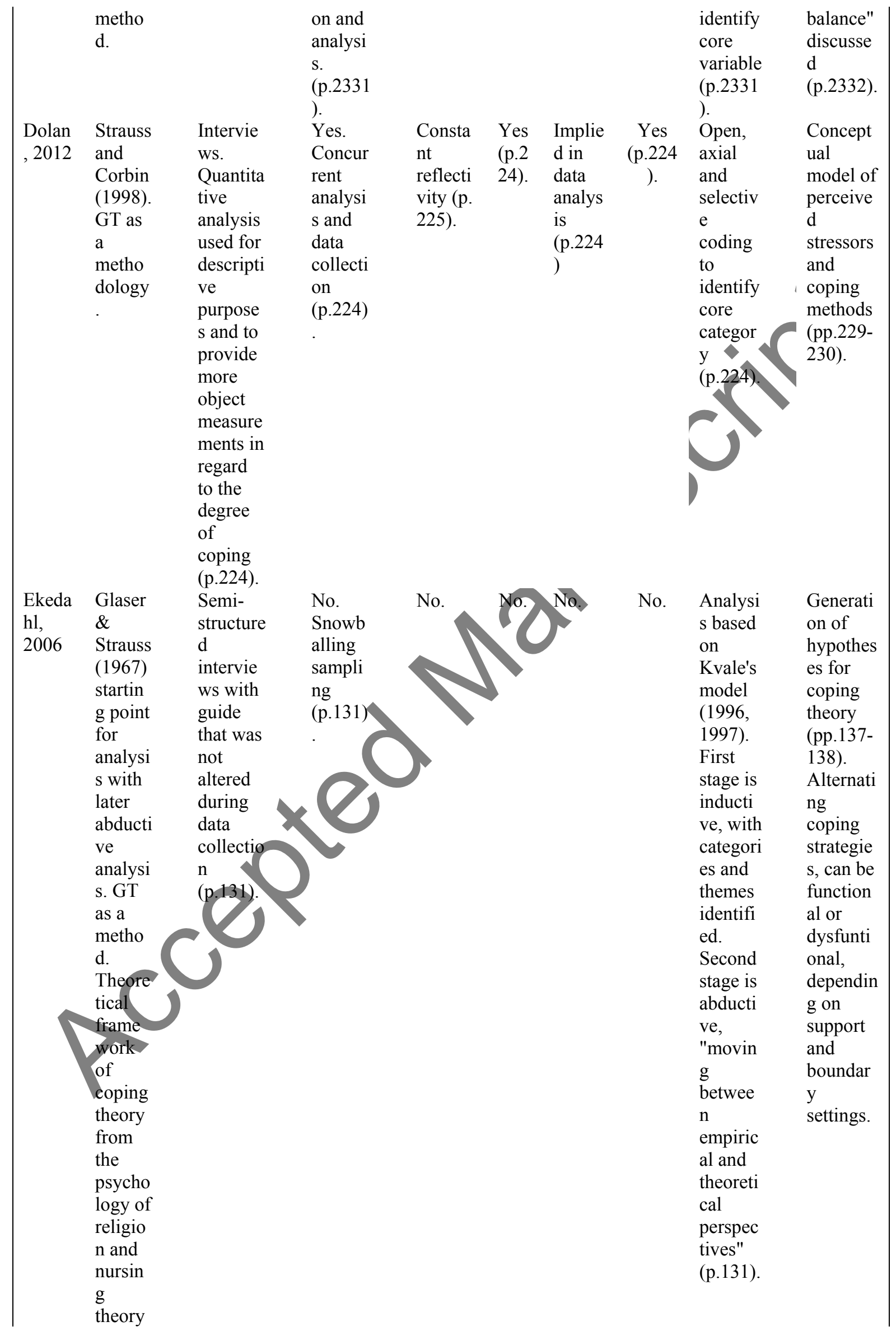


(p.130)

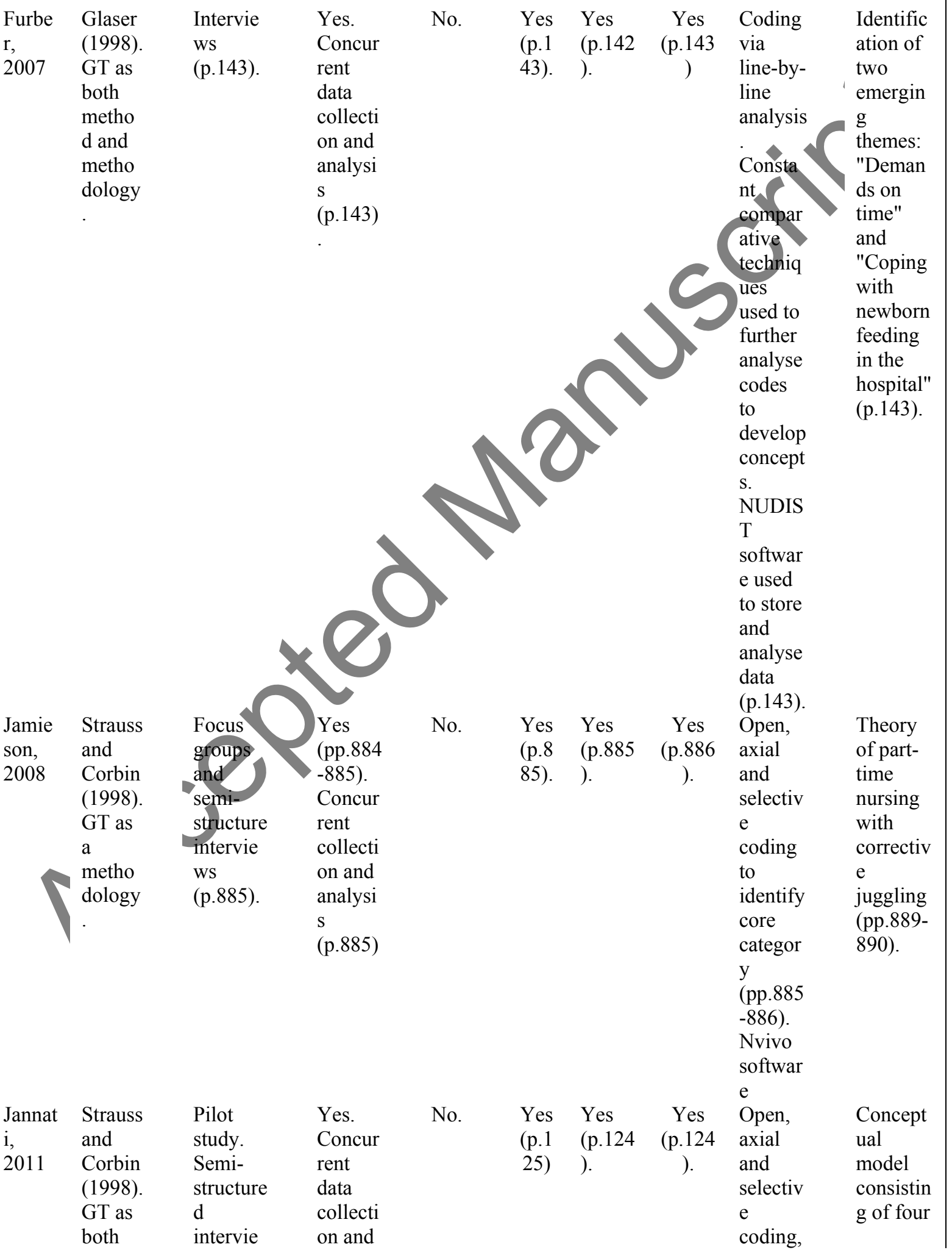




\begin{tabular}{|c|c|c|c|c|c|c|c|c|c|}
\hline & $\begin{array}{l}\text { metho } \\
\mathrm{d} \text { and } \\
\text { metho } \\
\text { dology } \\
\text {. }\end{array}$ & $\begin{array}{l}\text { ws and } \\
\text { participa } \\
\text { nt } \\
\text { observat } \\
\text { ion } \\
\text { (p.124). }\end{array}$ & $\begin{array}{l}\text { analysi } \\
\text { s } \\
\text { (p.124) } \\
\text {. }\end{array}$ & & & & & $\begin{array}{l}\text { idenfica } \\
\text { tion of } \\
\text { a core } \\
\text { variable } \\
\text { (p.125). } \\
\text { Coping } \\
\text { strategi } \\
\text { es } \\
\text { reporte } \\
\text { d } \\
\text { through } \\
\text { content } \\
\text { analysis } \\
\text { (p.124). }\end{array}$ & $\begin{array}{l}\text { phases } \\
\text { (p.127). }\end{array}$ \\
\hline $\begin{array}{l}\text { Lager } \\
\text { strom, } \\
2010\end{array}$ & $\begin{array}{l}\text { Charm } \\
\text { az } \\
(2006) \\
\text { using } \\
\text { Strauss } \\
\& \\
\text { Corbin } \\
\text { (1998) } \\
\text { analyti } \\
\text { cal } \\
\text { metho } \\
\text { ds. GT } \\
\text { as a } \\
\text { metho } \\
\text { d. }\end{array}$ & $\begin{array}{l}\text { Semi- } \\
\text { structure } \\
\mathrm{d} \\
\text { intervie } \\
\text { ws and } \\
\text { focus } \\
\text { groups. } \\
\text { Concurr } \\
\text { ent data } \\
\text { collectio } \\
\text { n and } \\
\text { analysis } \\
\text { (pp.167- } \\
\text { 168). }\end{array}$ & $\begin{array}{l}\text { Yes. } \\
\text { Concur } \\
\text { rent } \\
\text { data } \\
\text { collecti } \\
\text { on and } \\
\text { analysi } \\
\text { s. } \\
\text { (p.167) } \\
\text {. }\end{array}$ & No. & $\begin{array}{l}\text { Yes } \\
\text { (p.1 } \\
68) .\end{array}$ & $\begin{array}{l}\text { Yes } \\
\text { (p.168 } \\
) .\end{array}$ & $\begin{array}{c}\text { Yes } \\
\text { (p.168 } \\
\quad) .\end{array}$ & $\begin{array}{l}\text { Open, } \\
\text { axial } \\
\text { and } \\
\text { selectiv } \\
\text { coding } \\
\text { to } \\
\text { identify } \\
\text { core } \\
\text { categor } \\
\text { y } \\
\text { (p.168). }\end{array}$ & $\begin{array}{l}\text { Identific } \\
\text { ation of } \\
\text { core } \\
\text { theme } \\
\text { "Striving } \\
\text { for } \\
\text { balance } \\
\text { between } \\
\text { family } \\
\text { and } \\
\text { work } \\
\text { demands } \\
\text { " and } \\
\text { supporti } \\
\text { ng }\end{array}$ \\
\hline $\begin{array}{l}\text { Lipp, } \\
2009\end{array}$ & $\begin{array}{l}\text { Strauss } \\
\text { and } \\
\text { Corbin } \\
\text { (1990). } \\
\text { Suppor } \\
\text { ting } \\
\text { frame } \\
\text { work } \\
\text { of } \\
\text { femini } \\
\text { st } \\
\text { metho } \\
\text { dology }\end{array}$ & $\begin{array}{l}\text { Open- } \\
\text { ended } \\
\text { intervie } \\
\text { ws } \\
\text { (p.110). }\end{array}$ & $\begin{array}{l}\text { No, } \\
\text { homog } \\
\text { enous } \\
\text { then } \\
\text { purposi } \\
\text { ve } \\
\text { sampli } \\
\text { ng } \\
\text { (p.110) } \\
\text {. }\end{array}$ & & No. & $\begin{array}{l}\text { Yes } \\
\text { (p.110 } \\
) .\end{array}$ & No. & $\begin{array}{l}\text { Strauss } \\
\text { and } \\
\text { Corbin' } \\
\text { s } \\
\text { framew } \\
\text { ork } \\
\text { used to } \\
\text { categori } \\
\text { se the } \\
\text { data } \\
\text { and } \\
\text { constru } \\
\text { ct a } \\
\text { central } \\
\text { phenom } \\
\text { enon } \\
\text { (p. } \\
110) \text {. }\end{array}$ & $\begin{array}{l}\text { Applies } \\
\text { findings } \\
\text { to the } \\
\text { stress } \\
\text { model of } \\
\text { Carson } \\
\text { and } \\
\text { Kuipers } \\
\text { (1998), } \\
\text { with } \\
\text { stressors, } \\
\text { moderat } \\
\text { ors and } \\
\text { stress } \\
\text { outcome } \\
\text { s } \\
\text { (p.111). }\end{array}$ \\
\hline $\begin{array}{l}\text { Lipp, } \\
2008\end{array}$ & $\begin{array}{l}\text { Charm } \\
\text { az } \\
(2006) \\
\text { and } \\
\text { Strauss } \\
\text { and } \\
\text { Corbin }\end{array}$ & $\begin{array}{l}\text { Open- } \\
\text { ended } \\
\text { intervie } \\
\text { ws } \\
\text { (p.12). }\end{array}$ & $\begin{array}{l}\text { No, } \\
\text { homog } \\
\text { enous } \\
\text { then } \\
\text { purposi } \\
\text { ve } \\
\text { sampli }\end{array}$ & $\begin{array}{l}\text { Reflex } \\
\text { ivity. } \\
\text { Notes } \\
\text { that } \\
\text { author } \\
\text { "read } \\
\text { around }\end{array}$ & No. & $\begin{array}{l}\text { Yes } \\
\text { (p.12) }\end{array}$ & $\begin{array}{c}\text { Yes } \\
\text { (p.12) } \\
.\end{array}$ & $\begin{array}{l}\text { Open } \\
\text { coding, } \\
\text { comple } \\
\mathrm{x} \\
\text { coding } \\
\text { and } \\
\text { selectio }\end{array}$ & $\begin{array}{l}\text { Theory } \\
\text { of } \\
\text { fostering } \\
\text { a } \\
\text { woman- } \\
\text { centred }\end{array}$ \\
\hline
\end{tabular}




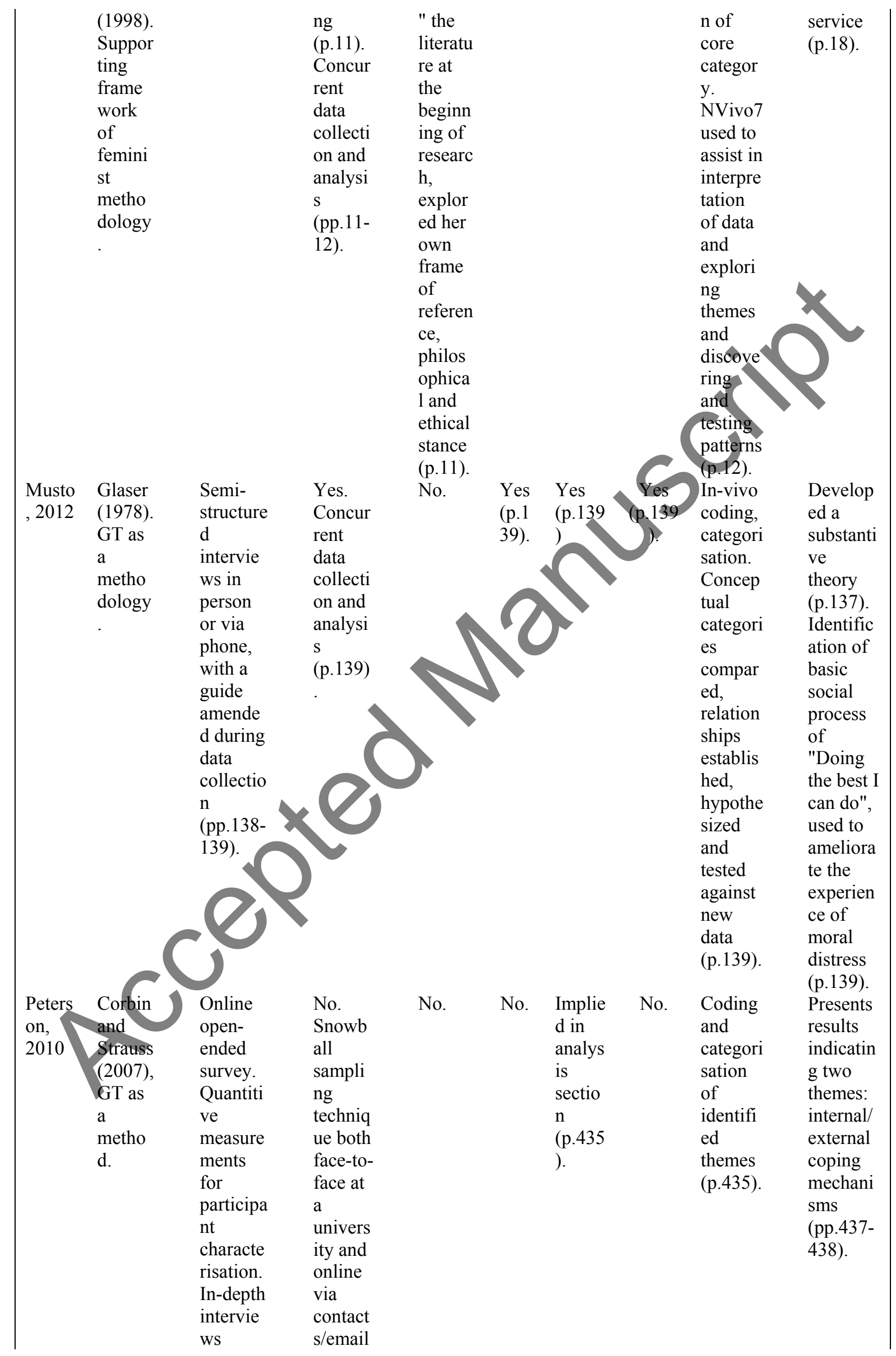




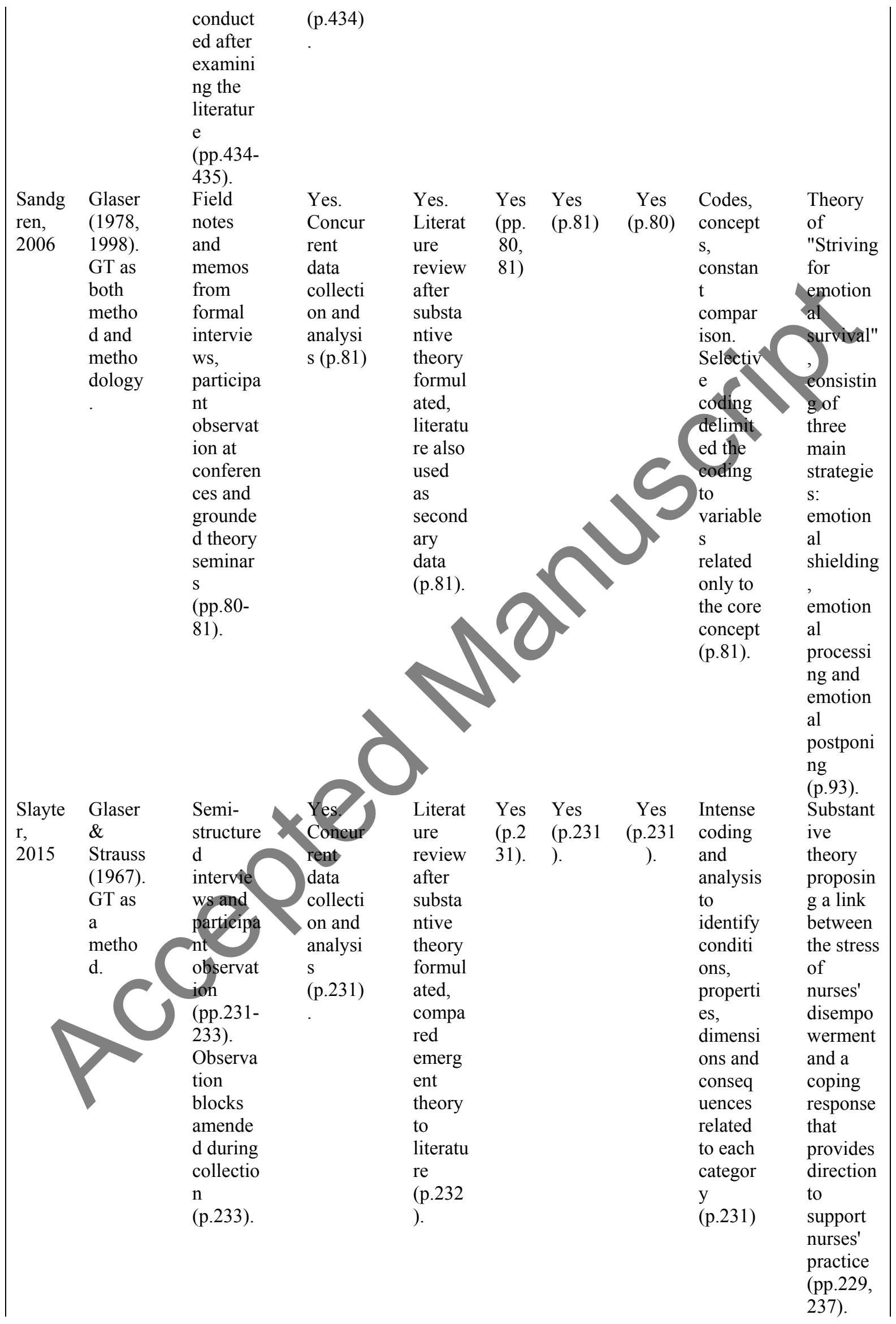




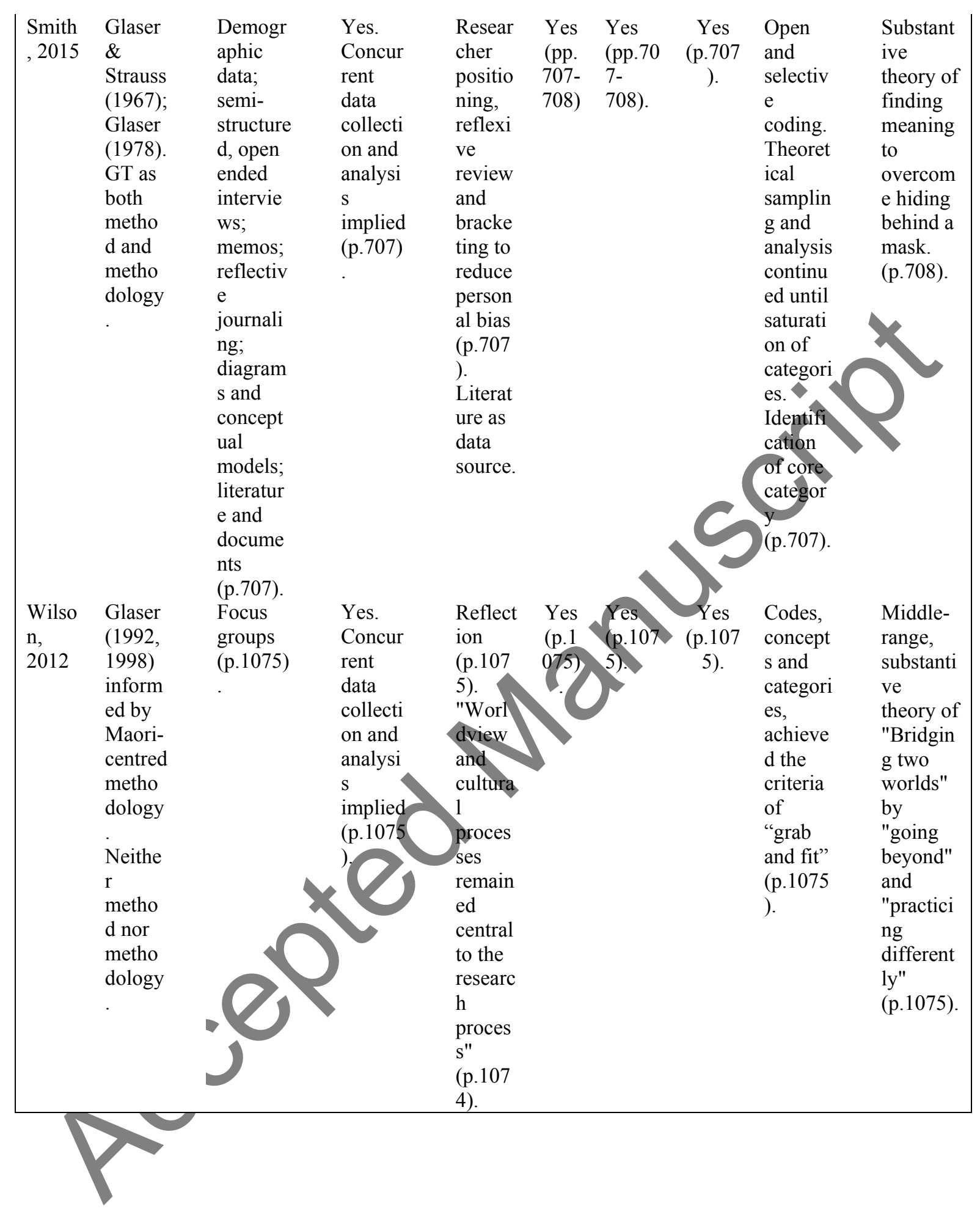




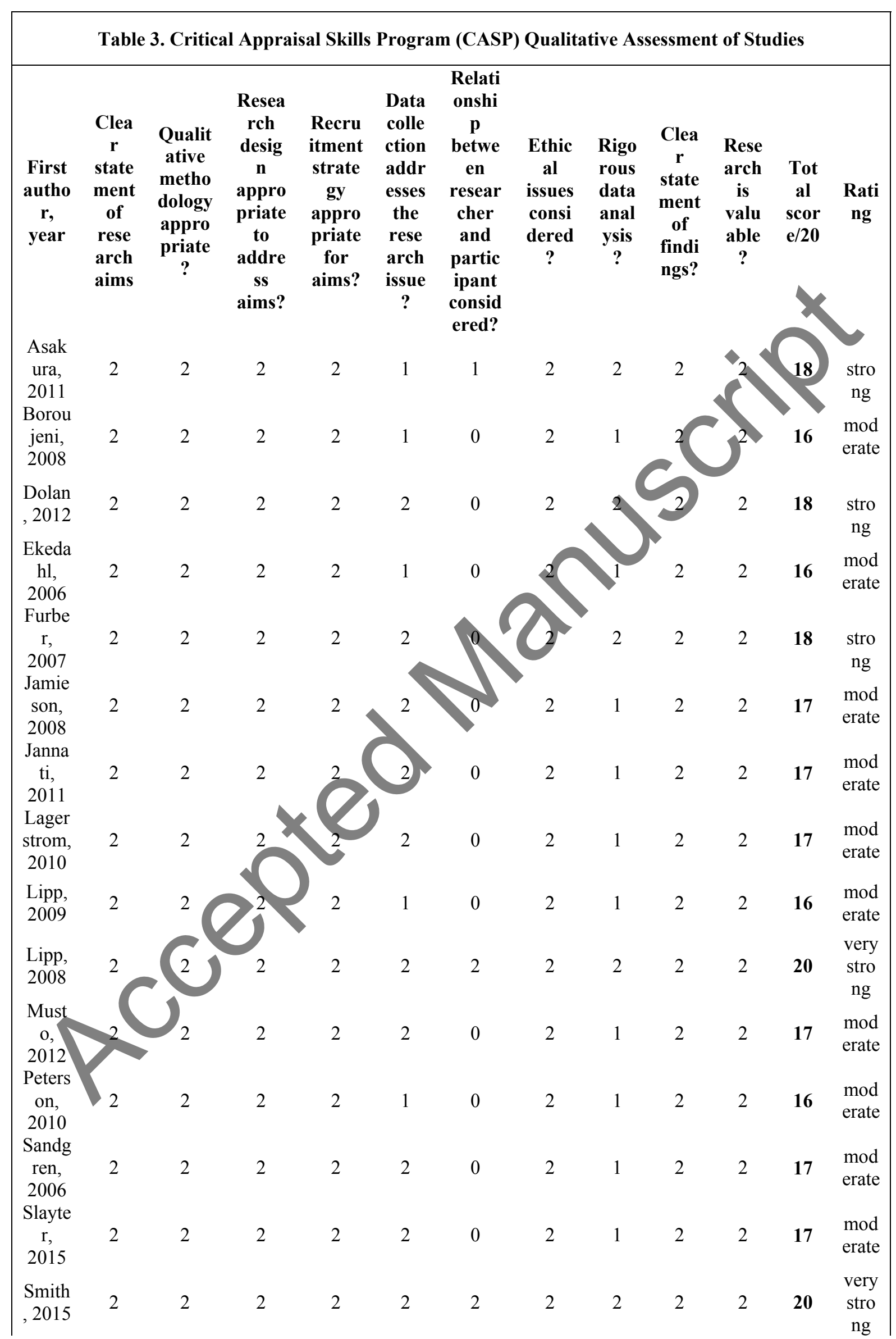




\begin{tabular}{|cccccccccccccc}
$\begin{array}{c}\text { Wilso } \\
\text { n, }\end{array}$ & 2 & 2 & 2 & 2 & 2 & 2 & 2 & 2 & 2 & 2 & $\mathbf{2 0}$ & $\begin{array}{c}\text { very } \\
\text { stro } \\
\text { ng }\end{array}$ \\
\hline
\end{tabular}

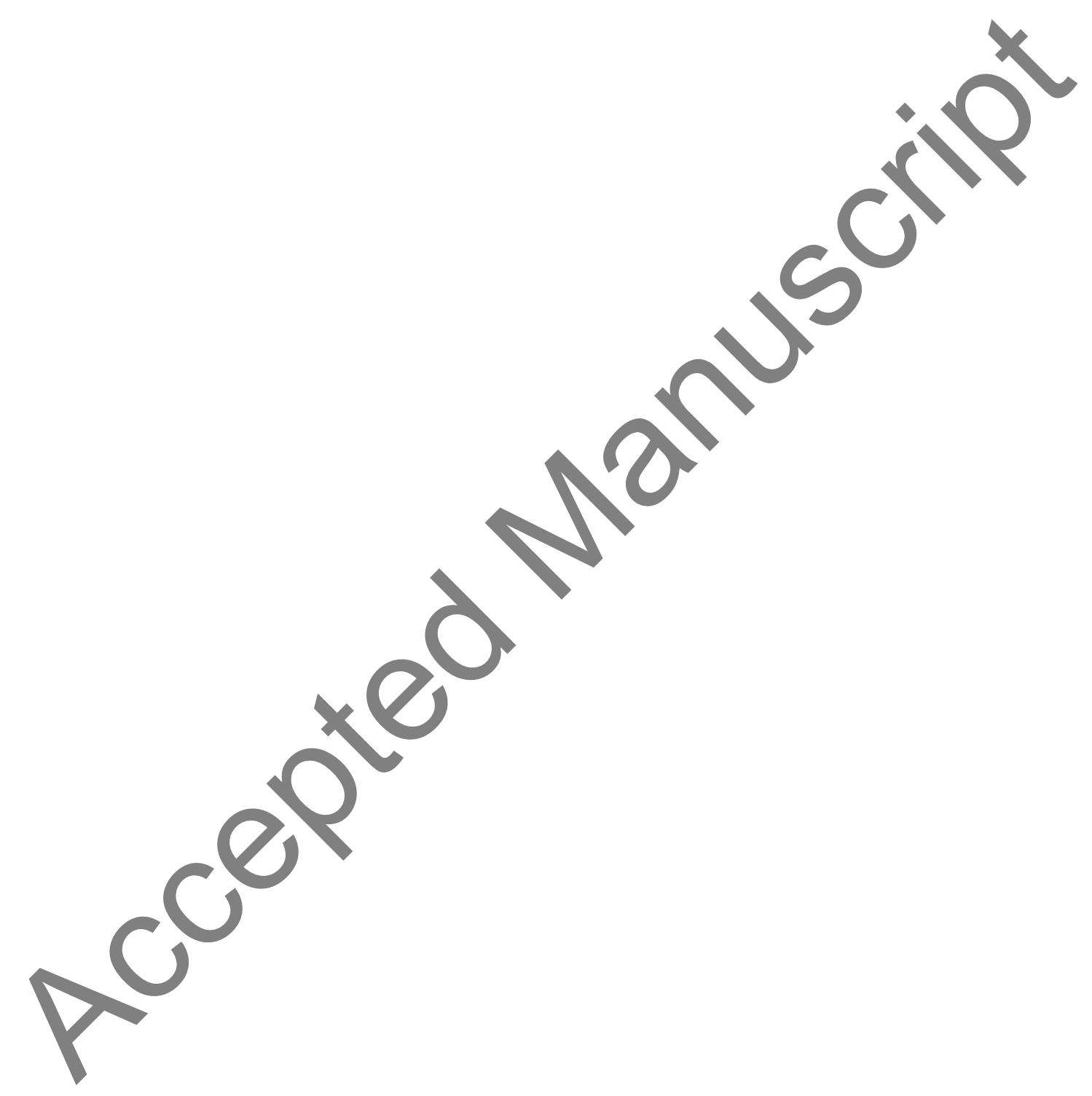




\section{PRISMA 2009 Flow Diagram}

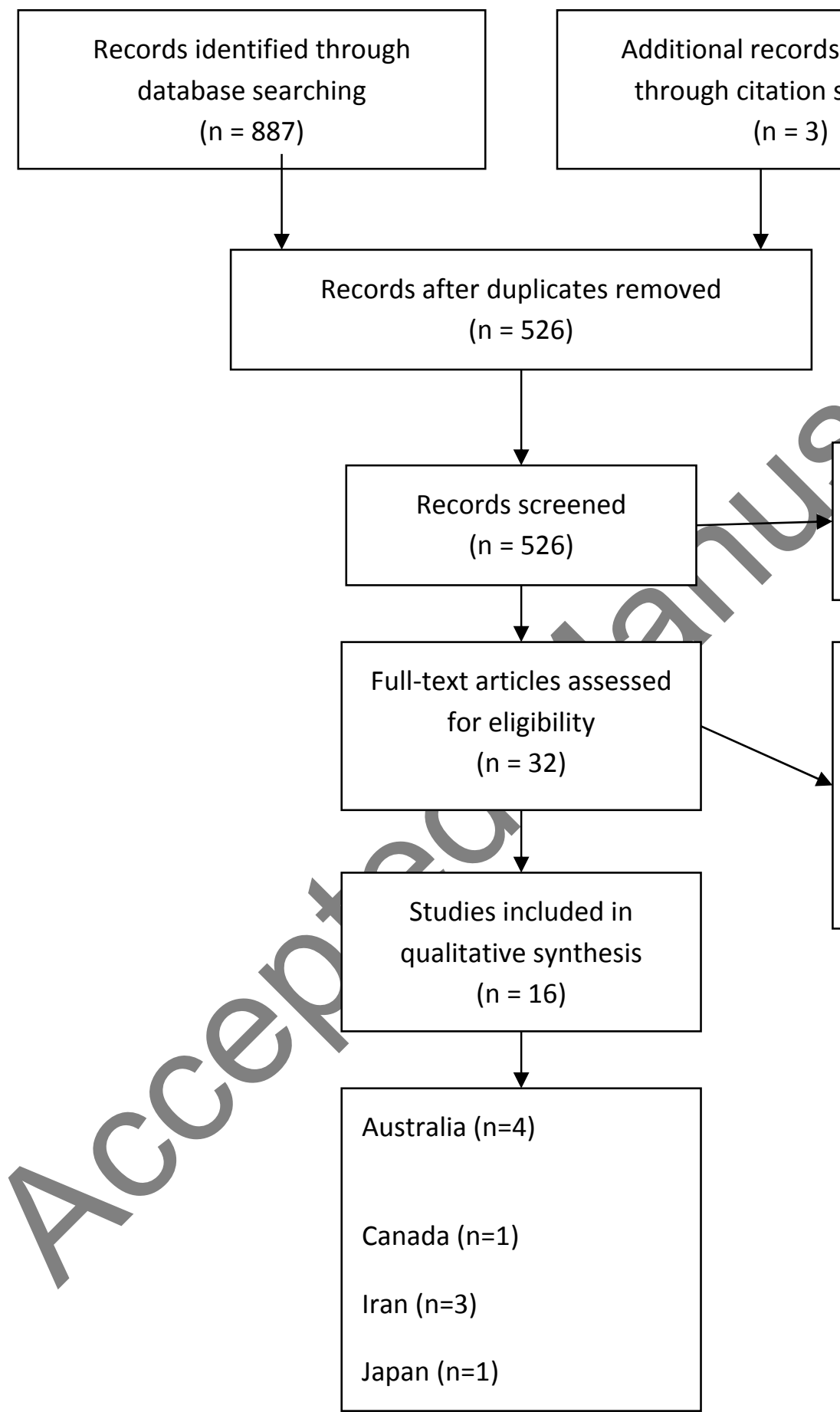

Records excluded after

screening of abstracts for

relevance $(n=496)$

Full-text articles excluded, with reasons

$(n=16)$

No methods section $(n=1)$

Not grounded theory methodology

From: Moher D, Liberati A, Tetzlaff J, Altman DG, The PRISMA Group (2009). Preferred Reporting /tems for Systematic Reviews and MetaAnalyses: The PRISMA Statement. PLoS Med 6(6): e1000097. doi:10.1371/journal.pmed1000097 